\title{
Zn incorporation in CuInSe 2 : Particle size and strain effects on microstructural and electrical properties
}

\author{
M BENABDESLEM*, A BOUASLA, N BENSLIM, L BECHIRI, S MEHDAOUI, \\ O AISSAOUI, A DJEKOUN, M FROMM ${ }^{\dagger}$ and X PORTIER ${ }^{\dagger \dagger}$ \\ Laboratoire LESIMS, Université d' Annaba, BP12, 23200 Sidi Amar, Algerie \\ ${ }^{\dagger}$ Centre de Microanalyse Nucléaire, UFR Science and Techniques, 16 route de Gray, 25030 Besançon, France \\ ${ }^{\dagger}$ CIMAP, ENSICAEN/Université de Caen, 6-Bd du Maréchal Juin 14050, Caen, France
}

MS received 3 April 2013; revised 13 April 2013

\begin{abstract}
Incorporation of the doping element $\mathrm{Zn}$ in the temperature range $\left(550-700{ }^{\circ} \mathrm{C}\right)$ and the impact on structural and electrical properties of $\mathrm{CuInSe}_{2}$ material are investigated. X-ray diffraction patterns showed the chalcopyrite nature of the pure and doped $\mathrm{CuInSe}_{2}$ and revealed that diffusion temperature governs particle size as well as tensile strain. The calculated lattice parameters and cell volumes revealed that $\mathrm{Zn}$ diffuses in $\mathrm{CuInSe}_{2}$ by substitution on $\mathrm{Cu}$ sites. Electrical properties of the material have been investigated using a contact-less technique based on high frequency microwave (HF). It is found that $\mathrm{Zn}$ atoms influence the defect equilibrium resulting in the conversion of the conduction type. The conductivity of the samples has been found increasing as the diffusion temperature increases.
\end{abstract}

Keywords. CuInSe $e_{2}$; doping; zinc; Williamson-Hall; high frequency.

\section{Introduction}

In recent years, the chalcopyrite $\mathrm{CuInSe}_{2}$ (CIS) has been investigated as a promising top candidate for use as a cell in photovoltaic systems because, it has a direct bandgap of $1 \mathrm{eV}$ which perfectly matches the solar spectrum for energy conversion and a high absorption coefficient $>10^{4} \mathrm{~cm}^{-1}$. CuInSe 2 is I.III. $\mathrm{VI}_{2}$ compound semiconductor and in general, this material displays $n$ - or $p$-type conductivity. Currently, the energy conversion efficiency of the best $\mathrm{CuInSe} \mathrm{S}_{2}$-based solar cell has reached $19 \%$ (Green et al 2007). However, several studies have been reported that during the production process of the cell $p$ $\mathrm{CuInSe}_{2} / n-\mathrm{CdS} / \mathrm{ZnO}(\mathrm{Al})$, interdiffusion of the elements via different interfaces may occur (Wada et al 1998; Heske et al 1999; Nakada and Kunioka 1999; Nakada 2000; Nakada and Mise 2001; Haug et al 2003; Nishiwaki et al 2003; Platzer-Björkman et al 2003). Interdiffusion of the elements across the interface is major problem which deteriorates the production quality of $\mathrm{CuInSe} \mathrm{S}_{2}$. When, it diffuses in $\mathrm{CuInSe}_{2}, \mathrm{Zn}$ acts as a donor and allows changing the conduction type and increasing in the conductivity (Benabdeslem et al 2005). Improvement of cell performance can be achieved by a better understanding of the mechanisms involved in the incorporation of

\footnotetext{
*Author for correspondence (benabdes@yahoo.fr)
}

$\mathrm{Zn}$ in $\mathrm{CuInSe}_{2}$ and the role of this element in the properties of the absorber. In the present work, we report on the effect of $\mathrm{Zn}$ diffusion on the lattice structure, composition and the conductivity in bulk $\mathrm{CuInSe}_{2}$ samples.

\section{Experiments}

Ingot of $\mathrm{CuInSe}_{2}$ was prepared by melting in vacuum a stoichiometric mixture made from pure $\mathrm{Cu}$, In and $\mathrm{Se}$ elements as described (Benabdeslem et al 2005). To carry out the Zn-related diffusion study, $0.5 \mathrm{~mm}$ thick circular wafers were cut from the central part of the $\mathrm{CuInSe}_{2}$ ingot and used as substrates on which $\mathrm{Zn}$ layers were deposited by evaporation at $2 \times 10^{-6}$ Torr. The specimens were then heated in ambient air at temperatures in the range (550$\left.700{ }^{\circ} \mathrm{C}\right)$. The thickness of $\mathrm{Zn}$ layer measured with vibrating quartz was $0.8 \mu \mathrm{m}$. The structural properties of the samples were characterized by X-ray diffraction (XRD) by means of a Phillips X-ray diffractometer powder using $\mathrm{CuK} \alpha_{1}$ radiation. The structural information was probed by SEM whereas the composition and the depth profiling by EDS. Zn content (in the bulk of each $\mathrm{CuInSe}_{2}$ piece) was measured along the thickness of the samples. The conduction type and the material conductivity were determined by respectively, the thermal probe method and the high frequency technique (HF) in a contactless way based on microwave resonance cavity (Gire et al 1997; Gevrey et al 2001; Benabdeslem et al 2007). 


\section{Experimental}

\subsection{Structural properties}

The homogeneity of the as grown ingot was further confirmed by taking extra concentration profiles of the different elements along growth and radial axes of the ingot. When compound semiconductors are grown, stoichiometric deviations can occur in the different parts of the ingot (first zone to freeze, middle and last zone to freeze) and this is due to the difference in vapour pressures of the constituent elements. For this reason, only the samples cut from the middle part of the compound with the correct composition were considered in this study. In order to confirm the existence of $\mathrm{Zn}$ inside the CuInSe $\mathrm{C}_{2}$ crystals, diffusion profiles of $\mathrm{Zn}$ were conducted by EDS as illustrated in figure 1 . Zn signals showed gradual profiles of diffusion for all samples. The diffusion profiles obtained were in good agreement with an erfc fitting. $\mathrm{X}$-ray diffraction analysis of $\mathrm{CuInSe}_{2}$ samples reported in figure 2 confirmed that $\mathrm{Zn}$-doped and pure $\mathrm{CuInSe}_{2}$ specimens crystallized in the chalcopyrite structure (JCPDS file card number 40-1487). With increasing diffusion temperature, the diffraction peaks became narrow. The line shrinking can be caused by both an increase in crystallite size and a decrease in lattice strain. It should be noted that XRD reflections are slightly right shifted as seen on the magnified (112) line. These internal stress modify the lattice parameters. Taking into account the quadratic form for the tetragonal system, the lattice constants $a$ and $c$ of the unit cell were calculated by the leastsquares fit method (Cullity 1971). The obtained values reported in table 1 showed a decrease of the lattice parameters and according to Bragg's law this means a

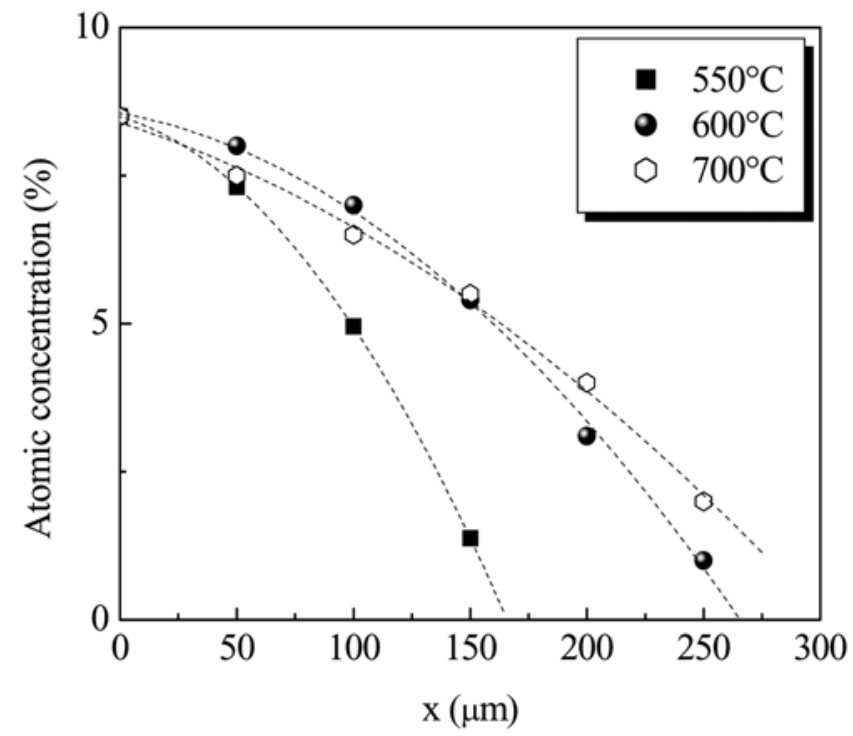

Figure 1. Concentration profiles of $\mathrm{Zn}$ in $\mathrm{CuInSe}_{2}$. slight contraction of the unit cell. This behaviour can be explained by the decrease of internal strain induced in the doped specimens. To estimate qualitative information regarding size and microstrain present in the doped samples. Williamson-Hall technique is used (Williamson and Hall 1953). In this method, both size and strain broadening are assumed to be Lorentzian:

$$
\beta_{\mathrm{total}}=\beta_{\mathrm{size}}+\beta_{\mathrm{strain}}=\beta \cos \theta=\frac{k \lambda}{D}+4 \varepsilon \sin \theta,
$$

$\varepsilon$ is the effective strain.

The size and strain were calculated for pure and $\mathrm{Zn}$ doped CuInSe $\mathrm{Cu}_{2}$ using (112), (211) and (316) planes. The curve $\beta \cos \theta$ vs $4 \sin \theta$ shows approximately a linear variation as seen in figure 3 . The effective crystallite size and strain are calculated using a linear equation; $y=A+\varepsilon x$. The slope of these lines gives strain $\varepsilon$ while their intercept on $y$-axis shows the effective crystallite size $D$. The positive slope on $\mathrm{Zn}$ doping samples indicate the presence of tensile strains in the crystal lattice. As the temperature is increased, the average crystallite size increases while the strain calculated from the graph decreases (table 1). The increase in crystallite size observed may be attributed to the replacement of smaller ionic radius of $\mathrm{Cu}^{2+}(70 \mathrm{pm})$ with slightly higher $\mathrm{Zn}^{2+}$ (74 pm) (Shannon 1976). The dislocation density $\Delta$ is calculated using Williamsons and Smallman's equation (Padiyan et al 2002):

$$
\Delta=\frac{1}{D^{2}}
$$

The dislocation density for the doped specimens shown in table 1 is highest among the studied crystals and for longer diffusion temperature, the density $\Delta$ decreases.

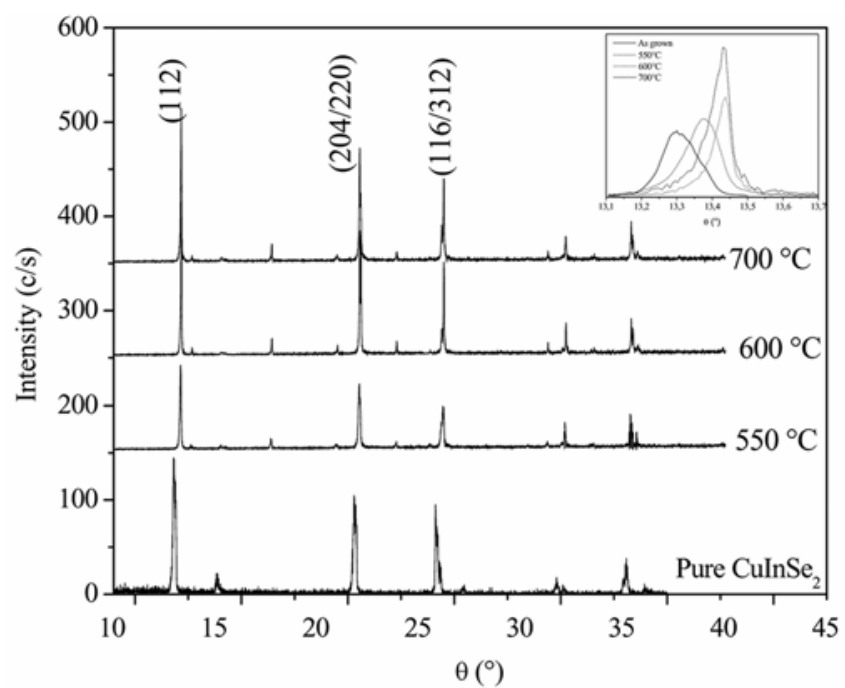

Figure 2. X-ray diffraction patterns of pure and Zn-doped $\mathrm{CuInSe} \mathrm{S}_{2}$ crystals. 
Table 1. Lattice parameters and volumes of as pure and $\mathrm{Zn}$-doped $\mathrm{CuInSe} \mathrm{I}_{2}$ crystals.

\begin{tabular}{lccccccc}
\hline & $a(\AA)$ & $c(\AA)$ & $c l a$ & $V\left(\AA^{3}\right)$ & $\begin{array}{c}\mathrm{W}-\mathrm{H} \\
D(\mathrm{~nm})\end{array}$ & $\varepsilon\left(10^{-4}\right)$ & $\begin{array}{c}\Delta\left(10^{15}\right) \\
\left(\text { lines } / \mathrm{m}^{2}\right)\end{array}$ \\
\hline Pure & 5.91 & 11.71 & 1.98 & 409.99 & 25 & - & $1.60 \times 10^{15}$ \\
$550^{\circ} \mathrm{C}$ & 5.81 & 11.62 & 2.00 & 392.46 & 171 & $4.57 \times 10^{-4}$ & $3.42 \times 10^{13}$ \\
$600^{\circ} \mathrm{C}$ & 5.77 & 11.61 & $2 \cdot 01$ & 387.20 & 250 & $5.87 \times 10^{-5}$ & $1.60 \times 10^{13}$ \\
$700^{\circ} \mathrm{C}$ & 5.78 & 11.62 & 2.01 & 388.71 & 237 & $6.25 \times 10^{-5}$ & $1.78 \times 10^{13}$ \\
\hline
\end{tabular}

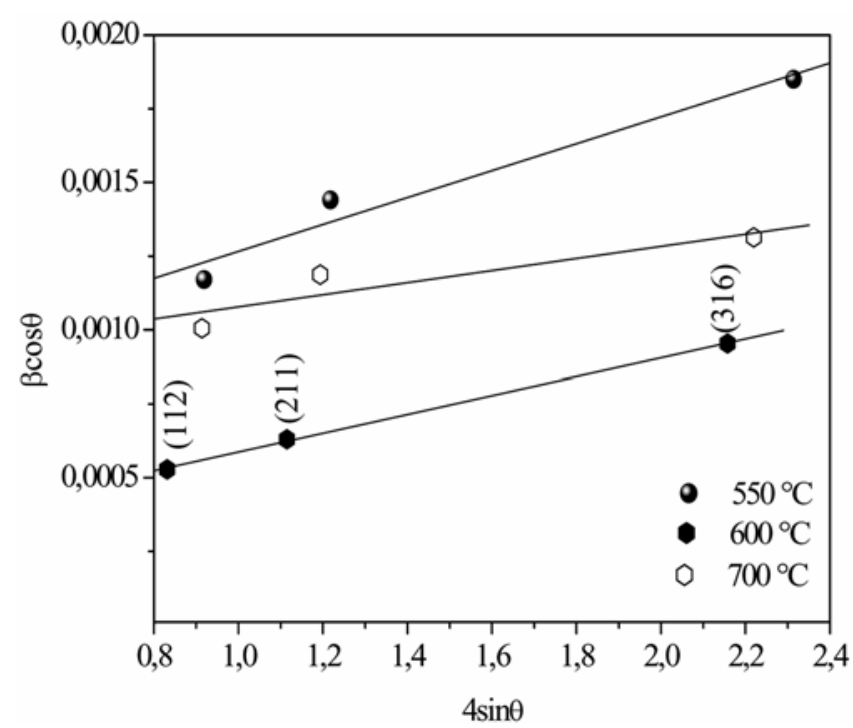

Figure 3. $\mathrm{W}-\mathrm{H}$ analysis of $\mathrm{Zn} / \mathrm{CuInSe} \mathrm{I}_{2}$ at different diffusion temperatures.

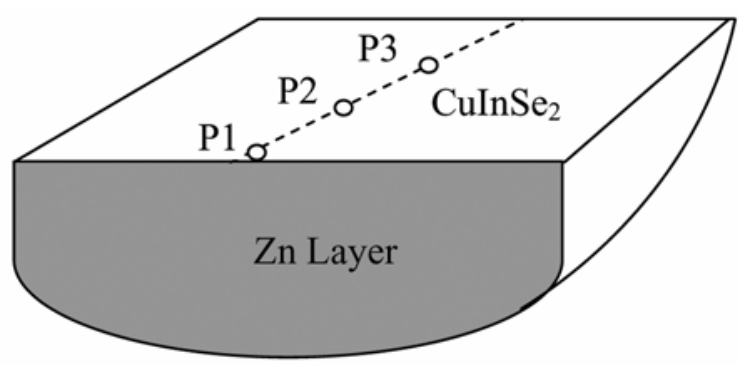

Figure 4. Positions of measured concentrations.

\subsection{Composition analysis}

Composition measurements were conducted on heated samples to determine the eventual changes in the content of different constituents in relation with the diffusion temperature. EDS analyses were made on several points labelled P1, P2 and P3 along the thickness of the doped samples as shown in figure 4 . The elevated concentration of $\mathrm{Cu}$ near the surface is reported in table 2, may be explained by the fact that the copper element is extremely mobile due to its lower activation energy $(0.35 \mathrm{eV})$, can migrate to the sample surface during the diffusion
Table 2. Composition of pure and $\mathrm{Zn}$-doped $\mathrm{CuInSe} \mathrm{e}_{2}$ crystals.

\begin{tabular}{|c|c|c|c|}
\hline $\begin{array}{l}\text { Diffusion } \\
\text { temperature }\end{array}$ & $\begin{array}{c}\mathrm{Cu} \\
(\text { at } \%)\end{array}$ & $\underset{(\text { at } \%)}{\operatorname{In}}$ & $\begin{array}{c}\mathrm{Se} \\
(\text { at } \%)\end{array}$ \\
\hline \multicolumn{4}{|l|}{$550{ }^{\circ} \mathrm{C}$} \\
\hline P1 & 23.29 & $27 \cdot 47$ & $46 \cdot 37$ \\
\hline P2 & $23 \cdot 12$ & $26 \cdot 56$ & $47 \cdot 28$ \\
\hline P3 & $21 \cdot 41$ & $26 \cdot 34$ & 49.52 \\
\hline \multicolumn{4}{|l|}{$600^{\circ} \mathrm{C}$} \\
\hline $\mathrm{P} 1$ & $28 \cdot 10$ & $25 \cdot 70$ & $43 \cdot 50$ \\
\hline $\mathrm{P} 2$ & $25 \cdot 30$ & $25 \cdot 50$ & $42 \cdot 50$ \\
\hline P3 & $22 \cdot 20$ & $24 \cdot 80$ & $41 \cdot 70$ \\
\hline \multicolumn{4}{|l|}{$700^{\circ} \mathrm{C}$} \\
\hline P1 & $32 \cdot 30$ & 23.07 & $43 \cdot 50$ \\
\hline P2 & $29 \cdot 35$ & 22.65 & $46 \cdot 36$ \\
\hline P3 & $24 \cdot 50$ & $24 \cdot 60$ & $36 \cdot 04$ \\
\hline
\end{tabular}

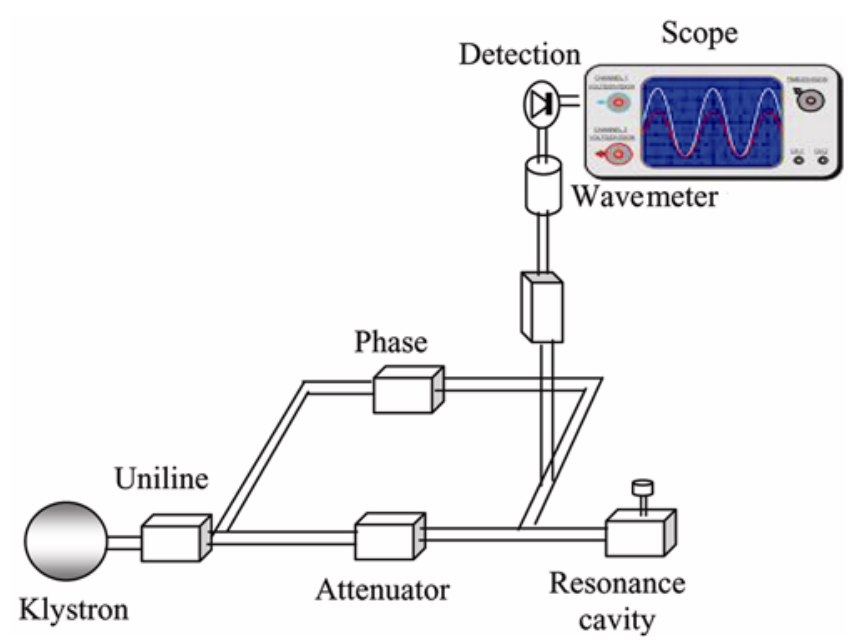

Figure 5. Experimental set up for HF conductivity measurements.

process. This behaviour is consistent with previous results, (Kenshole et al 1984). On the other hand, the In amount remains constant, whereas the decrease of Se is due to the sticking to the ampoule wall of this element is very volatile during the diffusion treatment. The variations in the content of the elements affect the properties of $\mathrm{CuInSe}_{2}$ and deteriorate the production quality of absorbers. 
Table 3. Electrical characteristics of as-grown and $\mathrm{Zn}$-doped $\mathrm{CuInSe} \mathrm{I}_{2}$ crystals.

\begin{tabular}{lccccc}
\hline$T\left({ }^{\circ} \mathrm{C}\right)$ & Time $(\mathrm{h})$ & Type & $\chi^{\prime} \times 10^{-3}$ & $\sigma_{\mathrm{HF}} \times 10^{-4}(\Omega \mathrm{cm})^{-1}$ & $\delta(\mathrm{mm})$ \\
\hline Pure & - & $p$ & 22 & 4.38 & 0.79 \\
550 & 36 & $n$ & 34 & 6.77 & 0.64 \\
600 & 24 & $n$ & 58 & 11.60 & 0.50 \\
700 & 8 & $n$ & 70 & 14.00 & 0.44 \\
\hline
\end{tabular}

\subsection{Electrical properties}

The study of complex permittivity of materials at high frequencies is an interesting tool in estimating the conductivity. Microwave technique in the opposite way to the classical d.c. method does not need electrical contacts which cause parasitic resistance. The high frequency conductivity is generally a complex quantity: $\sigma_{\mathrm{HF}}=\sigma_{1}-$ $i \sigma_{2}$ and can be determined from the measured values of the susceptibility as indicated by the following relation:

$$
\sigma=\varepsilon_{0} \omega \chi^{\prime \prime}=2 \pi f \varepsilon_{r} \varepsilon_{0} \chi^{\prime \prime}
$$

where $\varepsilon_{\mathrm{r}}$ is the permittivity of the free space $(8.85$. $\left.10^{-12} \mathrm{~F} / \mathrm{m}\right)$ and $\varepsilon_{\mathrm{r}}$ the permittivity of the semiconductor material (for $\mathrm{CuInSe}_{2}, \varepsilon_{\mathrm{r}}=3.9$ ). The electrical measurements based on the high frequency technique were performed at microwave frequency of $9192 \mathrm{MHz}$ in a resonant cavity as shown in figure 5. The high frequency conductivity values of pure and $\mathrm{Zn}$-doped $\mathrm{CuInSe}_{2}$ specimens are summarized in table 3 . The microwave assisted technique leads sometimes to high values of conductivity caused by the skin effect. The skin effect can be connected to the skin thickness using the equation:

$$
\delta=\sqrt{\frac{2}{\mu_{0} \sigma \omega}},
$$

$\mu_{0}$ represents the magnetic permittivity $\left(4 \pi \cdot 10^{-7}\right)$ and $\omega$ the pulsation of the a.c. signal.

The obtained values of the parameter $\delta$ reported in table 3 showed that the skin thickness is more important than the thickness of the samples. Thus, the electrical measurements are not disturbed by the skin effect because the samples were well adjusted in the belly of the electrical field. $\mathrm{Zn}$-doped $\mathrm{CuInSe}_{2}$ samples were found $n$ type and conducting. $V_{\mathrm{Cu}}$ are more likely than $V_{\mathrm{In}}$ because copper might participate weakly in the covalent bonding. Thus, the increase in the conductivity might be due to the occupation of $\mathrm{Cu}$ vacancies sites by $\mathrm{Zn}$ atoms and consequently to the creation of donor levels close to the conduction band.

\section{Conclusions}

$\mathrm{Zn}$ diffusion into stoichiometric $\mathrm{CuInSe}_{2}$ substrates under various temperatures $\left(550-700{ }^{\circ} \mathrm{C}\right)$ has been investigated. The properties of CuInSe $\mathrm{Se}_{2}$ were very sensitive to the diffu- sion process. The migration of $\mathrm{Zn}$ in $\mathrm{CuInSe}_{2}$ was confirmed by analysis of depth profiles and resulted in the deformation of the crystal lattice and hence reduced volumes (contraction of the cell lattice). The approach based on the deformation of the lattice crystal allows to confirm the diffusion kinetic of $\mathrm{Zn}$ in $\mathrm{CuInSe}_{2}$ which operates substitutionally on $\mathrm{Cu}$ sites. Hyper frequency microwave measurements showed $n$-type properties of the doped $\mathrm{CuInSe}_{2}$ crystals and as the diffusion temperature increases, the conductivity also increases. The factor responsible for this behaviour is thought to be $\mathrm{Zn}$ donors that occupy $\mathrm{Cu}$ sites.

\section{References}

Benabdeslem M, Benslim N, Bechiri L, Mahdjoubi L, Hannech E B and Nouet G 2005 J. Cryst. Growth 274144

Benabdeslem M et al 2007 Thin Solid Films 5156226

Cullity B D 1971 Elements of X-ray diffraction, Editorial Pueblo y Educación, p. 335

Gevrey F, Gire A, Gaudiot D, Théobald J G, Gheeraert E, Bernard M and Torrealba-Anzola F 2001 J. Appl. Phys. 904251

Gire A, Jouffroy M, Théobald J G, Bonhké O, Frand G and Lacorre P 1997 J. Phys. Chem. Solids 58577

Green M, Emery K, Hisikawa Y and Warta W 2007 Prog. Photovoltaics 15425

Haug F J, Rudmann D, Zogg H and Tiwari A N 2003 Thin Solid Films 431-432 431

Heske C et al 1999 Appl. Phys. Letts. 741451

Kenshole G E, Li C J, Toro C R and Loferski J J 1984 Photovoltaic solar energy conference, proceedings of the fifth international conference, Greece, p. 65

Nakada T 2000 Thin Solid Films 361346

Nakada T and Kunioka A 1999 Appl. Phys. Letts 742444

Nakada T and Mise T 2001 Proceedings of the 17th European photovoltaic solar energy conference, Munich, p. 1027

Nishiwaki S, Satoh T, Hashimoto Y, Shimakawa S I, Hayashi S, Negami T and Wada T 2003 Solar Energ. Mater. Solar C. 77359

Padiyan P, Marikani A and Murali K R 2002 Mater. Chem. Phys. 7851

Platzer-Björkman C, Lu J, Kessler J and Stolt L 2003 Thin Solid Films $\mathbf{4 3 1} 321$

Shannon R D 1976 Acta Crystallogr. A32 751

Wada T, Hayashi S, Hashimoto Y, Nishiwaki S, Sato T, Negami T and Nishitani M 1998 Proceedings of the second world conference on photovoltaic solar energy conversion, Vienna, p. 403

Williamson G K and Hall W H 1953 Acta Metall. 122 